Bangladesh J. Bot. 48(1): 145-151, 2019 (March)

\title{
INFLUENCE OF NATURAL SAFEROCK MINERAL ON SOIL MICRO- BILOGICAL PARAMETERS UNDER RICE-WHEAT CROPPING SYSTEM
}

\author{
Santosh Ranva ${ }^{1}$, YV Singh*, NeElam Jain ${ }^{1}$ and Deva Ram BaJiYa ${ }^{2}$ \\ ICAR-Indian Agricultural Research Institute, New Delhi 110012, India
}

Keywords: SafeRock Minerals, Aerobic rice, Wheat, Soil microbial activity, Nutrient management

\begin{abstract}
A field experiment was conducted to study the effect of SafeRock Minerals (SRM) application on soil microbiological parameters in rice-wheat cropping system. The experiments consisted of two methods of rice and wheat establishment and six different levels of crop nutrition including SRM with mineral fertilizers and organic manure (FYM). The rice was grown in kharif (June to October) season through aerobic direct seeded condition and flooded transplanted system. During rabi (October to April) season wheat was cultivated by two establishment methods viz. system of wheat intensification (SWI) and conventional wheat. The high yielding varieties of Basmati rice (Pusa Basmati 1509) and wheat (HD 2967) were used in the experiment. The results revealed that the soils of rice and wheat crops showed significant improvement in available $\mathrm{N}, \mathrm{P}$ and $\mathrm{K}$ and soil microbial parameters (enzymatic activities and microbial biomass carbon) due to the integrated application of $250 \mathrm{~kg} / \mathrm{ha} \mathrm{SRM}+100 \%$ recommended dose of fertilizer (RDF) and $250 \mathrm{~kg} / \mathrm{ha} \mathrm{SRM}$ $+50 \% \mathrm{RDF}$ (chemical) + 25\% RDF (organic) and $250 \mathrm{~kg} / \mathrm{ha} \mathrm{SRM} \mathrm{+} \mathrm{50 \%} \mathrm{organic-FYM} \mathrm{(10.0} \mathrm{t/ha)} \mathrm{over} \mathrm{the}$ sole SRM application under both the methods of stand establishment of rice as well as wheat.
\end{abstract}

\section{Introduction}

Rice and wheat are the world's two most important cereal crops, contributing $45 \%$ of the digestible energy and $30 \%$ of total protein in the human diet (Alam et al. 2014). In South Asia, rice-wheat crop sequence is the largest agriculture production system and occupies about 13.5 million hectares area including 10.5 million hectares in India, extending from Indo-Gangetic plain to Himalayan foothills (Singh and Kaur 2012, Sister et al. 2013). In spite of such a vital significance of rice-wheat cropping system in providing food security and livelihood to hundreds of millions of people around the globe the questions have arisen regarding the sustainability of the system due to various environmental, economic and management problems encountered in areas following this production system (Upadhyay et al. 2014).

SafeRock mineral is a natural mineral resource which can be used to reduce dependence on chemical fertilizers, as it contains many of the minerals (P 0.5\%, K 5.5\%) and trace elements ( $\mathrm{Si}$ $21 \%, \mathrm{Ca} 1.2 \%, \mathrm{Mg} 1.3 \%, \mathrm{Al} 4.5 \%, \mathrm{Fe} 2.2 \%, \mathrm{Na} 1.6 \%$ ) essential for healthy crops and livestock. It has been recently discovered in the United Kingdom. SafeRock Minerals are reported to provide a natural holistic solution to help to mitigate the global crisis of soil degradation and water scarcity. It has shown to be agronomically effective, slow-release fertilizers that can provide many macroand micronutrients to enhance soil fertility and restore soil fertility in the long-term. It has the greatest affinity for ammonium and potassium but when a plant is taking up the ammonium or potassium off the SRM, it attracts calcium from the phosphorus mineral apatite, such as rock phosphate, or locked up phosphorus in soil to balance the SRM, negative charge. This is reported to be achieved through its unique balance of nutrients and clay minerals, which also increases microbial and earthworm activity and builds long term soil fertility (www.saferockminerals.com).

\footnotetext{
*Author for correspondence: yvsingh63@yahoo.co.in. ${ }^{1}$ Amity Institute of Biotechnology, Amity University Rajasthan, Jaipur, India. ${ }^{2}$ Division of Bioscience, Institute of Pesticide Formulation Technology, Sector-20, Udyog Vihar, NH-8, Gurgaon 122016, India.
} 
Soil microorganisms play an important role in the soil environment. They are the critical factors that determine soil organic matter decomposition, nutrient cycling, soil degradation and bioremediation of soil pollution (Larkin 2003, Li et al. 2012). Some studies have documented that fertilization has had significant impacts on the population, composition and function of soil microorganisms, and that organic and inorganic fertilizer amendments have increased the soil microorganisms' activity (Mandal et al. 2007, Ge et al. 2008). However, other studies have demonstrated that inorganic and organic fertilizers have had relatively little or no effect on soil microbial diversity and activities (Treseder 2008, Kabirigi et al. 2017). Long-term fertilization experiments can be controlled so as to modify soils in a particular manner and so can contribute significantly to existing knowledge about the evolution of soil fertility, the effects of fertilization, nutrient cycling in croplands, as well as soil biogeochemical cycles (Kstjasteinauer et al. 2015). Thus, research on soil microorganism communities under long-term fertilizer management has been one of the foci of soil ecological research in recent years (Yamaguchi et al. 2009, Wen Yi Dong et al. 2014). Geiseller and Scow (2014) published a meta-analysis based on 107 datasets from 64 long-term experiments from around the world and revealed that mineral fertilizer application led to a significant increase $(15.1 \%)$ in the microbial biomass above levels in the unfertilized control treatments (Rebecca et al. 2017). With the above background, an experiment was conducted to study the effects of SRM application on microbiological parameters of soil in rice-wheat cropping system.

\section{Materials and Methods}

The field and laboratory experiments were conducted during 2016-17 and 2017-18 at the research farm of ICAR-Indian Agricultural Research Institute, New Delhi, India. The institute farm is located at a latitude of $28^{\circ} 40^{\prime} \mathrm{N}$ and longitude of $77^{\circ} 12^{\prime} \mathrm{E}$ with an altitude of 228.6 meters above the mean sea level (Arabian Sea). Before beginning of experiments composite soil sample of same field was having $144.6 \mathrm{~kg} / \mathrm{ha}$ alkaline permanganate oxidizable $\mathrm{N}$ (Subbiah and Asija 1956), $14.7 \mathrm{~kg} / \mathrm{ha}$ available $\mathrm{P}$ (Olsen et al. 1954), $261.5 \mathrm{~kg} 1 \mathrm{~N}$ ammonium acetate exchangeable $\mathrm{K}$. The $\mathrm{pH}$ of soil was 7.8 ( $1: 2.5$ soil and water ratio).

The experiment was laid out in randomized block design (RBD) with six treatments and replicated thrice which were statistically analyzed using the F-test following Gomez and Gomez (1984). LSD values at $p=0.05$ were used to determine the significance of difference between treatment means. The following six treatments were included:

- No SafeRock Minerals (SRM) application $+100 \%$ RDF* $\left(\mathrm{N}_{120} \mathrm{P}_{60} \mathrm{~K}_{60}\right)$ - control

- Only SRM application @ 250 kg/ha

- SRM application @ $250 \mathrm{~kg} / \mathrm{ha}+50 \% \mathrm{RDF}\left(\mathrm{N}_{60} \mathrm{P}_{30} \mathrm{~K}_{30}\right)$

- SRM application @ $250 \mathrm{~kg} / \mathrm{ha}+100 \% \mathrm{RDF}$

- SRM application @ 250 kg/ha + $50 \%$ RDF (Chemical)+ $25 \%$ RDF (Organic-FYM 10 t/ha)

- SRM application @ $250 \mathrm{~kg} / \mathrm{ha}+50 \%$ RDF (Organic-FYM)

*Recommended dose of fertilizer

Basmati (aromatic) rice variety 'Pusa Basmati 1509' and wheat variety 'HD 2967' were taken in rice and wheat crops, respectively. Rice was grown under direct sown aerobic and puddled transplanted conditions whereas, wheat was grown under conventional and system of wheat intensification (SWI) condition. In transplanted rice 21 days old seedlings were transplanted after land preparation through puddling. Two seedlings were transplanted per hill. General recommendations for the crop were followed for performing all other agronomic practices excluding the treatments. 
For analysis of microbial biomass carbon (MBC) the method described by Nunan et al. (1998) was followed. Enzyme analyses were carried out by using following method described by Tabatabai and Bremner (1969). Dehydrogenase was estimated by the method given by Klein $e t$ al. (1971). Fluorescein diacetate (FDA) enzyme was analysed by the method given by Green et al. (2006).

\section{Results and Discussion}

Status of microbial biomass carbon (MBC) in soil at 30,60 DAS/DAT and crop maturity stage was significantly influenced due to the integrated application of SafeRock mineral with mineral and organic sources of nutrients (Table 1). MBC in soil was lowest with sole application of SRM and higher with SRM $+100 \%$ RDF and integrated application of organic and mineral nutrient sources. Application or organic sources also enhanced the MBC in general. MBC was found to vary between 167.10 and 215.12 and 222.24 to $238.66 \mu \mathrm{g} \mathrm{MBC/g}$ soils in aerobic rice and 188.11 to 220.45 and 228.22 to $274.43 \mu \mathrm{g} \mathrm{MBC/g}$ soils in transplanted rice and 169.43 to 208.66 and 224.13 to $260.66 \mu \mathrm{g} \mathrm{MBC/g}$ soils in conventional wheat and 182.33 to 211.66 and 230.32 to $261.18 \mu \mathrm{g} \mathrm{MBC/g}$ soils in system of wheat intensification $30 \mathrm{DAS}$ and $60 \mathrm{DAS}$ and crop maturity stage, respectively. The highest $\mathrm{MBC}(274.43 \mu \mathrm{g} \mathrm{MBC} / \mathrm{g}$ soil) in rice and MBC $(261.18 \mu \mathrm{g} \mathrm{MBC} / \mathrm{g}$ soils) in wheat were recorded with $250 \mathrm{~kg} \mathrm{SRM}+100 \% \mathrm{RDF}$ and it was statistically different from rest of the treatment. The treatment with sole SRM recorded lowest MBC as compared to other treatment under aerobic as well as transplanted and conventional as well as system of wheat intensification conditions. MBC content further increased due to combined application of SRM with organic material (FYM) compared to their sole application mineral fertilizer. Soil MBC declined at crop harvest stage while it was highest at 60 DAS/DAT. Similar results were reported by Geiseller and Scow (2014) who published a meta-analysis based on 107 data sets from 64 long-term experiments from around the world and revealed that mineral fertilizer application led to a significant increase $(15.1 \%)$ in the microbial biomass above levels in the unfertilized control treatments.

Alkaline phosphatase enzyme activity in soil at 30 and 60 DAS/DAT and crop harvest stage of rice and wheat were significantly influenced due to the application of SRM with mineral fertilizers and organic sources as compared to sole SRM application (Table 2). Alkaline phosphatase enzyme activity was significantly higher at $250 \mathrm{~kg} / \mathrm{ha}$ SRM $+100 \%$ RDF $\left(\mathrm{N}_{120} \mathrm{P}_{60} \mathrm{~K}_{60}\right)$ than other treatments while lowest activity was recorded at only SRM application. Alkaline phosphatase enzyme activity with $250 \mathrm{~kg} / \mathrm{ha}$ SRM + 100\% RDF was highest and it was significantly higher over sole $250 \mathrm{~kg} / \mathrm{ha}$ SRM application. Alkaline phosphatase enzyme activity through SRM + 100 RDF was at par with integrated application of mineral fertilizers and organic manure. Treatment having combined application of SRM and organic manure showed higher alkaline phosphatase enzyme activity than sole application of mineral fertilizers in most of the observations. Alkaline phosphatase enzyme was declined at crop harvest stage while it was highest at 60 DAS/DAT. Nath et al. (2011) also reported increased phosphatase activity in rice due to the application of rock phosphate.

Like alkaline phosphatase enzyme activity and dehydrogenase enzyme activity in soil at 30 and $60 \mathrm{DAS} / \mathrm{DAT}$ and crop harvest stage of rice and wheat crop increased significantly due to the integrated application of $250 \mathrm{~kg} / \mathrm{ha}$ SRM with other mineral fertilizers and organic manures over the sole SRM application (Table 3). Dehydrogenase enzyme activity was significantly highest at $250 \mathrm{~kg}$ P/ha through SRM $+100 \%$ RDF while lowest activity was recorded at sole SRM application. Dehydrogenase enzyme activity with $250 \mathrm{~kg} / \mathrm{ha}$ SRM $+100 \% \mathrm{RDF}$ was significantly higher over $250 \mathrm{~kg}$ P/ha SRM, $250 \mathrm{~kg} / \mathrm{ha} \mathrm{SRM}+50 \% \mathrm{RDF}$ and found at par with No SRM +100\% 

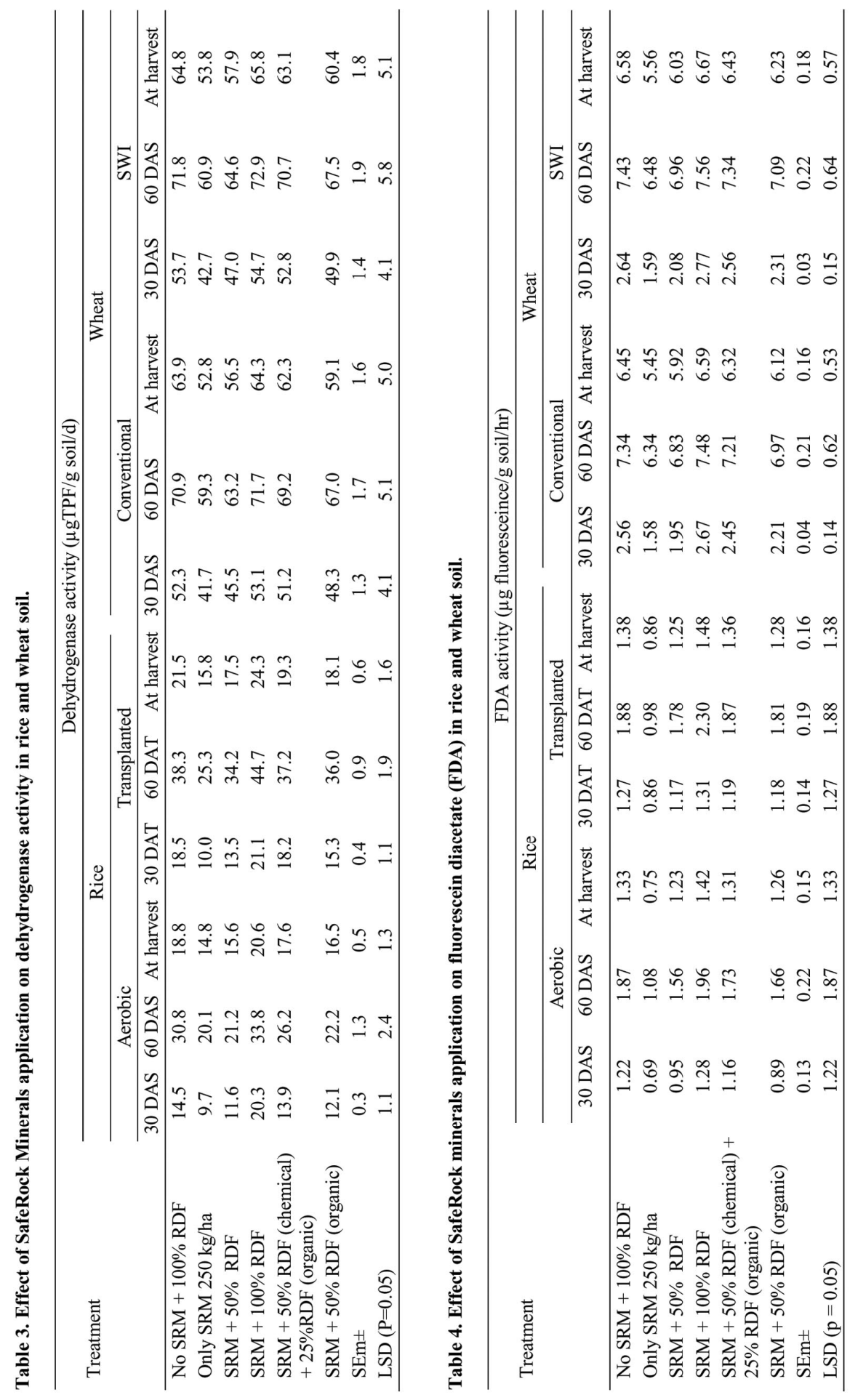
$\mathrm{RDF}$ and SRM+ 50\% RDF (chemical) $+25 \%$ RDF (organic). Treatment having integrated application of SRM with FYM showed higher dehydrogenase enzyme activity than sole mineral fertilizer application. Dehydrogenase enzyme activity declined at crop harvest stage while it was highest at 60 DAS/DAT. Nath et al. (2011) also reported increased dehydrogenase activity in rice due to the application of rock phosphate.

Fluorescein diacetate (FDA) enzyme activity recorded in rice soil at 30 and 60 DAS/DAT and crop harvest stage of rice and wheat crop were found to increase significantly due to the integrated application of SRM with mineral fertilizer and organic manure over sole SRM application (Table 4). FDA enzyme activity was significantly higher than $250 \mathrm{~kg} / \mathrm{ha}$ SRM $+100 \%$ RDF than other treatments while lowest activity was recorded at only SRM. FDA enzyme activity with $250 \mathrm{~kg} / \mathrm{ha}$ through SRM + 100\% RDF was significantly higher over $250 \mathrm{~kg} / \mathrm{ha}$ SRM, SRM + 50\% RDF and were found to be at par with no SRM + 100\% RDF and SRM + 50\% RDF (chemical) + 25\% RDF (organic). Treatment having combined application of SRM showed higher FDA enzyme activity than sole application. FDA enzyme activity was found to decline at crop harvest stage while it was highest at $60 \mathrm{DAS} / \mathrm{DAT}$.

In the present study, MBC and other parameters of rice and wheat were positively influenced by the integrated application of SRM in both the years. Integrated inoculation of $250 \mathrm{~kg} / \mathrm{ha} \mathrm{SRM} \mathrm{+}$ $50 \%$ organic-FYM (10 t/ha) was found to be suitable combination for enhancing the microbial activities in soils of rice and wheat. This treatment was significantly better than the application of only SRM $250 \mathrm{~kg} / \mathrm{ha}$. Thus, integrated application of $250 \mathrm{~kg} / \mathrm{ha}$ SRM $+50 \%$ organic-FYM (10 $\mathrm{t} / \mathrm{ha}$ ) may be appropriate dose for rice-wheat cropping system and therefore may be recommended for rice-wheat system in Indo-gangatic plains of south Asia.

\section{Acknowledgements}

The authors gratefully acknowledge Mr. John Jeremiah and Ashish Arora from M/s SafeRock Minerals Pvt. Ltd. for financial support to conduct this research.

\section{References}

Alam MK, Islam MM, Salahin N and Hasanuzzaman M 2014. Effect of tillage practices on soil properties and crop productivity in wheat-mungbean-rice cropping system under subtropical climatic conditions. Sci. World J. 8: 1-15.

Ge Y, Zhang J, Zhang L, Yang, M and He J 2008. Long-term fertilization regimes affect bacterial community structure and diversity of an agricultural soil in northern China. J. Soils Sediments 8: 43-50.

Geiseller D and Scow KM 2014. Long term effects on mineral fertilizers on soil microorganisms- a review. Soil Biol. Biochem. 75: 54-63

Gomez KA and Gomez AA 1984. Statistical procedures for agricultural research. 2nd edition. An International Rice Research Institute Book. A Wiley-Inter science publication, John Wiley \& Sons, New York. 680p.

Green VS, Ctott DE and Diack M 2006. Assay of fluorescein diacetate hydrolytic activity - optimization of soil samples. Soil Biology Biochem. 38: 693-701.

Kabirigi M, Prakash SO, Prescella BV, Niamwiza C, Quintin SP, Mwamjengwa IA, Jayantha AM, Keji MLA and Zhang C 2017. Fertigation for Environmentally Friendly Fertilizers Application: Constraints and Opportunities for Its Application in Developing Countries. Agric Sciences. 8: 292-301.

Katjasteinauer, David Tilman, Peter D Wragg, Simone Cesarz, Jane M Cowles, Karin Pritsch, Peter B Reich, Wolfaang W Weisser and Nico eisenhauer 2015. Plant diversity effects on soil microbial functions and enzymes are stronger than warming in a grassland experiment. Ecology 96: 99-112.

Klein DA, Loh TC and Goulding RL 1971. A rapid procedure to evaluate dehydrogenase activity of soils low in organic matter. Soil Biol. Biochem. 3: 385-387 
Larkin RP 2003. Characterization of soil microbial communities under different potato cropping systems by microbial population dynamics, substrate utilization and fatty acid profiles. Soil Biol. Biochem. 35: 1451-1466.

Li Y, Chen YL, Li M, Lin XG and Liu RJ 2012. Effects of arbuscular mycorrhizal fungi communities on soil quality and the growth of cucumber seedlings in a greenhouse soil of continuously planting cucumber. Pedosphere 22: 79-87.

Mandal A, Patra AK, Singh D, Swarup A, Ebhin Masto R 2007. Effect of long-term application of manure and fertilizer on biological and biochemical activities in soil during crop development stages. Bioresour. Technol. 98: 3585-3592.

Nath DJ, Ozah B, Baruah R, Barooah RC and Borah DK 2011. Effect of integrated nutrient management on soil enzymes, microbial biomass carbon and bacterial populations under rice (Oryza sativa)-wheat (Triticum aestivum) sequence. Indian J. Agric. Sci. 81(12): 1143-1148.

Nunan N, Morgan MA and Herlihy M 1998. Ultraviolet absorbance (280 nm) of compounds released from soil during chloroform fumigation as an estimate of the microbial biomass. Soil Biology Biochemistry 300(12): 1599-1603.

Olsen B C, Cole CV, Watenabe FS and Dean LA 1954. Estimation of available phosphorus by extraction with sodium carbonate, USDA Circular Number 939: 19.

Rebecca F, Graham Sam E, Wortman and Cameron M Pittelkow 2017. Comparison of organic and integrated nutrient management strategies for reducing soil $\mathrm{N}_{2} \mathrm{O}$ emissions. Sustainability 9: 510 .

Singh A and Kaur J 2012. Impact of conservation tillage on soil properties in rice-wheat cropping system. Agric. Sci. Res. J. 2: 30-41.

Sister M, Raveloson H, Tharreau D and Dusserre J 2013. Conservation agriculture cropping system to limit blast disease in upland rainfed rice. Plant Pathol. 63: 373-381.

Subbiah BV and Asija GL 1956. A rapid procedure for the estimation of available nitrogen in soils. Current Sci. 25 (8): 259-260.

Tabatabai MA and Bremner JM 1969. Use of p-nitrophenyl phosphate for assay of soil phosphatase activity. Soil Biol. Biochem. 1: 301-307

Treseder KK 2008. Nitrogen additions and microbial biomass: a meta-analysis of ecosystem studies. Ecol. Lett. 11: 1111-1120.

Upadhyay V, Vaish SS and Bhardwaj NR 2014. Effect of resource conservation practices and conventional practices on population dynamics of Meloidogyne graminicola under rice-wheat cropping system. Afr J Microbiol Res. 8: 3025-3028.

Wen Yi Dong, Xin-Yu Zhanga, Xiao-Qin Daia, Xiao-Li Fua, Feng-Ting Yanga, Xi-Yu Liua, Xiao-Min Suna, Xue-Fa Wena and Sean Schaefferb 2014. Changes in soil microbial community composition in response to fertilization of paddy soils in subtropical China. Applied Soil Ecology 84: 140-147.

Yamaguchi N, Kawasaki A and liyama I 2009. Distribution of uranium in soil components of agricultural fields after long-term application of phosphate fertilizers. Sci. Total Environ. 407: 1383-1390. 